\title{
Effect of Soil Artificially Polluted with Lead on an Invasive Fallopia $x$ bohemica: A Case Study from Central Europe
}

\author{
Justyna Soltysiak, Teresa Brej* \\ Department of Botany and Plant Ecology, Wrocław University of Environmental and Life Sciences, \\ Wrocław, Poland
}

Received: 16 May 2018

Accepted: 10 September 2018

\begin{abstract}
The presented study was carried out to estimate the effects of lead on an invasive Fallopia $\mathrm{x}$ bohemica. The plant material was hexaploid hybrid, which was collected from riparian habitat of Wrocław (SW Poland) and cultivated under greenhouse conditions. Plants were grown in control pots and in pots with soil artificially polluted with various doses of $\mathrm{Pb}\left(50,100,200 \mathrm{mg} \cdot \mathrm{kg}^{-1}\right)$ for 98 days. To determine the ability of tested hybrids to grow under stress conditions we tested their morphological characteristics (fresh and dry weight of aboveground parts, fresh and dry weight of underground parts, length of shoots, length and width of leaves, number of leaves). The lead content in the rhizomes was also determined for roots and leaves separately. In the greenhouse experiment, the rhizomes of Fallopia $\mathrm{x}$ bohemica regenerated well in the polluted soil. The increase in the concentration of lead in soil did not negatively affect its growth and morphological characteristics. The tested hybrid accumulated lead, mainly in underground parts. The mean $\mathrm{Pb}$ content in plants from the soil where $200 \mathrm{mg} \cdot \mathrm{kg}^{-1}$ of $\mathrm{Pb}$ was added was more than 20 times higher than in control plants. The results suggest that the invasive Fallopia $\mathrm{x}$ bohemica is tolerant to lead pollution, what can facilitate its intensive expansion on anthropogenic soils, where the level of this metal is usually high.
\end{abstract}

Keywords: invasive plant species, Japanese Knotweed s.l., hybrid, lead

\section{Introduction}

Pollution with heavy metals is one of the most noticeable environmental problems due to their adverse ecological effects reported by many publications [1-3]. Toxic metals contaminating the soils create difficult

*e-mail: justyna.soltysiak@upwr.edu.pl

conditions for most plants growing in them. They may cause various morphological, physiological, and biochemical dysfunctions in plants, either directly or indirectly, and cause damaging effects [2]. Heavy metal toxicity in plants varies with plant species, specific metal, content of metal, its chemical form, soil composition and $\mathrm{pH}$. Some metals, including $\mathrm{Cu}, \mathrm{Mg}$, $\mathrm{Co}, \mathrm{Zn}$ and $\mathrm{Cr}$, are essential to plants in trace amounts, but only when metals are present in bioavailable forms, and at excessive levels they have the potential to become toxic to plants [4]. Others, such as $\mathrm{Mg}$, 
$\mathrm{Co}$, and $\mathrm{Zn}$, have unknown biological functions and can cause disorders even in relatively lower contents [5].

Fallopia $\mathrm{x}$ bohemica (Chrtek et Chrtková) J.P. Bailey is an interspecific hybrid between two Asian herbaceous perennial species Fallopia japonica var. japonica (Houtt.) Ronse Decraene and Fallopia sachalinensis (F. Schmidt ex Maxim.). All belong to the Fallopia genus, (Polygonaceae), but as it creates a polyploid complex of species it is often referred to as Japanese Knotweed s.l. [6]. Members of the Fallopia genus differ in their genetic variation. Among them, Fallopia x bohemica shows the highest genetic variability and three ploidy levels $(2 \mathrm{n}=44,66$ and 88) [6,7], and show various invading abilities. Fallopia $\mathrm{x}$ bohemica is considered the most troublesome plant of the Fallopia genus [8]. The hybrid spreads faster than the parental species and is ecologically better adapted to human-influenced environments due to its higher regenerative ability [7]. Fallopia x bohemica strongly competes with other plant species, even with its parents at the areas where taxa cooccur [9]. Moreover, among invasive taxa of the Fallopia genus, the hybrid has the greatest resistance to chemical eradication [10]. In Central Europe, the Fallopia genus willingly invades habitats changed by human influence. They occur frequently in places with a high level of anthropogenic impact, including areas along roads and railway tracks [7,11]. The Fallopia genus can inhabit soils polluted by heavy metals. In some areas of Central Europe, Japanese Knotweed s.l. can grow on soils where the maximum values of heavy metals reach up to: $79.7 \mathrm{mg} \cdot \mathrm{kg}^{-1}(\mathrm{Cu}), 158.1 \mathrm{mg} \cdot \mathrm{kg}^{-1}(\mathrm{~Pb})$ and $500 \mathrm{mg} \cdot \mathrm{kg}^{-1}(\mathrm{Zn})$ in the case of Fallopia japonica [12], and $51.6 \mathrm{mg} \cdot \mathrm{kg}^{-1}(\mathrm{Cu}), \mathrm{Pb} 216.3 \mathrm{mg} \cdot \mathrm{kg}^{-1}(\mathrm{~Pb})$ and $448.8 \mathrm{mg} \cdot \mathrm{kg}^{-1}(\mathrm{Zn})$ for Fallopia $\mathrm{x}$ bohemica [13]. It was also observed that the hybrid range in such places increases quickly [13].

In this study, we examined the effect of lead on Fallopia $\mathrm{x}$ bohemica growing under greenhouse conditions. This metal was tested because it belongs to the major pollutants connected with anthropogenic activities and it is toxic to most plants species. We hypothesized that the Fallopia $\mathrm{x}$ bohemia hybrid is tolerant to lead pollution, which can facilitate its intensive expansion on anthropogenic soils, where the content of this metal is usually high. The presented experiment is the first step to verify this hypothesis. Its main goal was to answer the questions: 1) Does the presence of high lead doses in soils affect the regeneration ability of Fallopia x bohemia from rhizome fragments?, 2) Does the tested hybrid tend to accumulate
$\mathrm{Pb}$ ?, and 3) Does $\mathrm{Pb}$ influence Fallopia x bohemica's growth and its chosen morphological characteristics?

\section{Materials and Methods}

\section{Greenhouse Experiment}

To evaluate the response of Fallopia $\mathrm{x}$ bohemica to lead pollution in soil, a greenhouse investigation was carried out. In this study, we used Fallopia x bohemica hybrid with chromosome number (66) and ploidy level $(2 n=66)$. The experiment was designed with three doses of lead $\left(50,100\right.$ and $\left.200 \mathrm{mg} \cdot \mathrm{kg}^{-1}\right)$, which were applied into plastic pots, each containing $5 \mathrm{~kg}$ of soil with known chemical properties (Table 1). The pots with soil without the addition of $\mathrm{Pb}$ were treated as the control. All lead treatments and the control were tested in four replications. Plants were grown from the last week of May to the end of August under natural light and temperature conditions. During the experiment, the air temperature varied from 20 to $30^{\circ} \mathrm{C}$. The research material was fresh rhizome fragments of Fallopia $\mathrm{x}$ bohemica. Fallopia taxa as invasive plants, spread mainly in a vegetative way on newly settled areas, usually by rhizome fragments [4]. For this reason, the rhizomes were used to establish the plants in the experiment. The plant material for the experiment was collected from riparian habitat of the Odra River at $51^{\circ} 06.035^{\prime} \mathrm{N}, 17^{\circ} 04.643^{\prime} \mathrm{E}$ in the city of Wroclaw (SW Poland). The locality was selected on the basis of published data [13] and represents a place where the content of lead does not exceed its average level, which for uncontaminated Polish soils is reported as $18 \mathrm{mg} \cdot \mathrm{kg}^{-1}$ [14].

The dug-out rhizomes were cleaned from the soil with a brush and rinsed with distilled water. Next, they were divided into 10-centimeter fragments of the same weight $(14,5 \mathrm{~g})$. Single rhizome fragments were placed at a depth of $5 \mathrm{~cm}$ into the $\mathrm{Pb}$ treatment and control pots. Plants in the greenhouse were grown for 98 days. To determine the ability of the tested hybrid to grow under stress conditions, its morphological characteristics (fresh and dry weight of aboveground parts, fresh and dry weight of underground parts, length of shoots, length and width of leaves, number of leaves) were measured. Next, the lead concentration in plant tissues was determined. Lead belongs to metals that accumulate in underground parts of plants [5, 15]. Generally, the content of $\mathrm{Pb}$ in plant organs tends to decrease in the following order: roots $>$ leaves $>$ stems $>$ flowers [15].

Table 1. Chemical properties of soil used in the greenhouse experiment.

\begin{tabular}{|c|c|c|c|c|c|c|c|}
\hline \multicolumn{2}{|c|}{$\mathrm{pH}$} & $\mathrm{N}_{\mathrm{og}}$ & $\mathrm{C}_{\mathrm{og}}$ & $\mathrm{K}_{2} \mathrm{O}$ & $\mathrm{P}_{2} \mathrm{O}_{5}$ & $\mathrm{MgO}$ & \multirow{2}{*}{$\begin{array}{c}\text { Agronomical } \\
\text { Category }\end{array}$} \\
\hline $\mathrm{K}_{\mathrm{Cl}}$ & $\mathrm{H}_{2} \mathrm{O}$ & \multicolumn{2}{|c|}{$[\%]$} & \multicolumn{3}{|c|}{$\left[\mathrm{mg} 100 \cdot \mathrm{g}^{-1}\right]$} & \\
\hline 5.9 & 6.3 & 0.092 & 1.4 & 32.6 & 13.5 & 4.7 & Medium soil \\
\hline
\end{tabular}


Taking this into account, underground (rhizomes with roots) and aboveground organs (leaves) of Fallopia $\mathrm{x}$ bohemica were treated separately, as different parts of the plants accumulate $\mathrm{Pb}$. The stems and flowers as organs that contain a smaller amount of this metal were not analyzed. Plant material was washed with distilled water. Soil particles were removed carefully from the underground parts of plants. Plant samples were air-dried at $85^{\circ} \mathrm{C}$ and milled with a stainless-steel grinder. Next, the samples were digested in a mixture of $\mathrm{HCl}$ and $\mathrm{HNO}_{3}$ (in a ratio 3:1) [16]. Concentrations of heavy metals in plant tissues were analyzed by the ICP-OES technique using a Varian 220 analytical machine. Each sample was analyzed in four replicates.

\section{Statistical Analysis}

The Shapiro-Wilk W test was used to check the normal distribution of data. The homogeneity of variance was checked by Levene's test. The data of normal distribution were analyzed using oneway ANOVA with post-hoc testing of significance of differences using Tukey's test, in which the test statistic (F) and probability value (p) were taken into account. The data for which a normal distribution was not found, or the homogeneity of variance was not obtained, were analyzed using non-parametric methods, the Kruskal-Wallis test, where attention was paid to the test statistic $(\mathrm{H})$ and probability value $(\mathrm{p})$. To determine the relationship between the studied biometric features of Fallopia x bohemica, principal correspondence component analysis (PCA) was used. Data used in the analyses were transformed logarithmically. Statistical analyses were conducted using the STATISTICA v. 12 (StatSoft Inc., 2014) package.

\section{Results and Discussion}

The Fallopia genus has massive vegetative regeneration abilities, especially from rhizome segments. Brock et al. [17] have shown that in natural conditions, a new plant can be created from a small rhizome segment (even up to approximately $0.7 \mathrm{~g}$ in weight). The results of the presented study showed that high doses of lead $\left(50,100,200 \mathrm{mg} \cdot \mathrm{kg}^{-1}\right)$ did not induce a delay of the regeneration of rhizomes of Fallopia x bohemica. New plants regenerated after 4 days in control pots as well as in all pots with contaminated soils.

It is known that excessive lead accumulation in plant tissue impairs various morphological, physiological, and biochemical functions [18]. Common changes in morphological characteristics of plants induced by excess lead can include the reduction in size and thickness of leaf blade or shrinking and distortion of the leaves, and lead can also decrease plant height [19]. The variability of all studied morphological features of Fallopia x bohemica are shown in Fig. 1. Based on the analysis of the PCA diagram, it was concluded that the first canonical axis cumulated $29.5 \%$ of the total

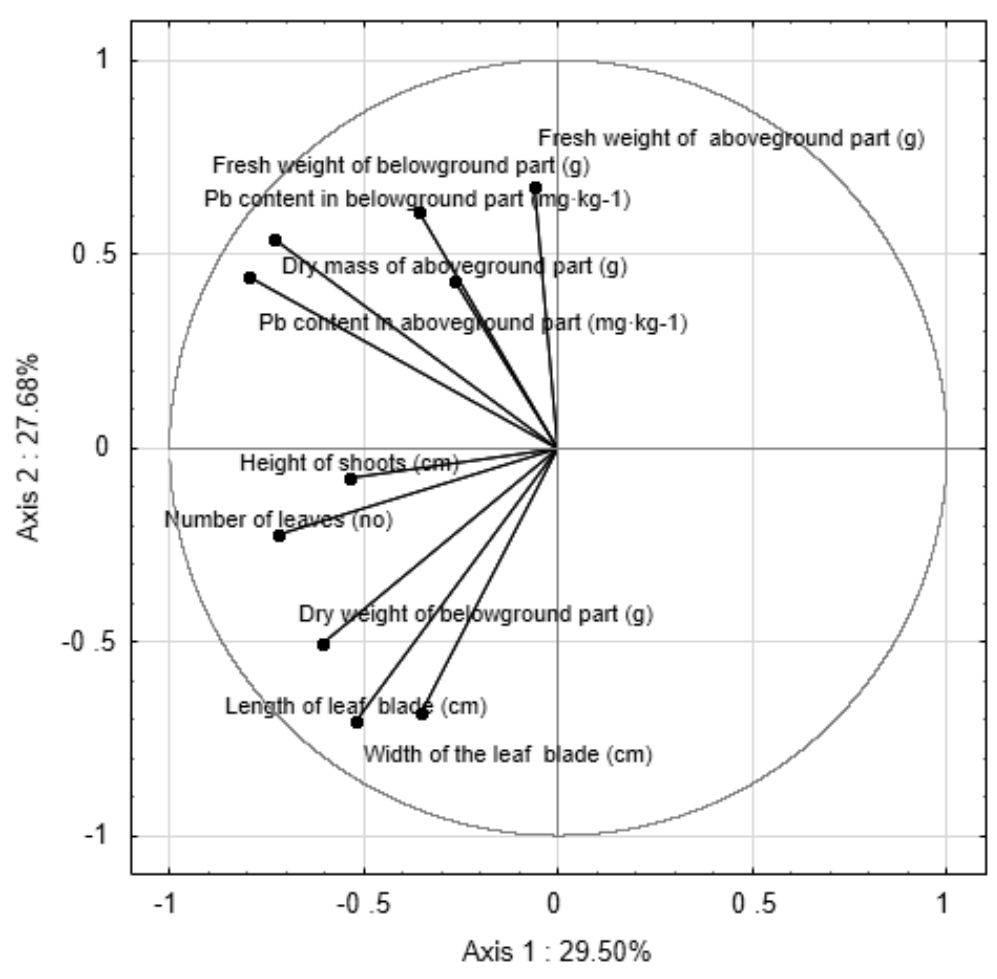

Fig. 1. Results of PCA in the first and second canonical axes; analysis was prepared for all biometric features and the content of $\mathrm{Pb}$ in underground and aboveground parts of plant bodies. 
Table 2. Comparison of morphological characteristics of Fallopia $\mathrm{x}$ bohemica and the content of lead in aboveground and underground part of plants from pots polluted with various levels of $\mathrm{Pb}$; the table shows mean values with standard errors; different letters present significant differences obtained after Tukey's test* and Kruskal-Wallis test $(\mathrm{P} \leq 0.05)$.

\begin{tabular}{|c|c|c|c|c|c|}
\hline \multicolumn{2}{|l|}{ Characteristics } & \multirow{2}{*}{$\begin{array}{c}\text { Control } \\
87.86 \mathrm{a} \\
( \pm 12.68)\end{array}$} & \multirow{2}{*}{$\begin{array}{c}50 \mathrm{mg} \cdot \mathrm{kg}^{-1} \\
68.98 \mathrm{a} \\
( \pm 11.57)\end{array}$} & \multirow{2}{*}{$\begin{array}{c}100 \mathrm{mg} \cdot \mathrm{kg}^{-1} \\
74.76 \mathrm{a} \\
( \pm 5.52)\end{array}$} & \multirow{2}{*}{$\begin{array}{c}200 \mathrm{mg} \cdot \mathrm{kg}^{-} \\
\begin{array}{c}102.16 \mathrm{a} \\
( \pm 14.78)\end{array}\end{array}$} \\
\hline Dry weight of under-ground & $\mathrm{g}$ & & & & \\
\hline Fresh weight of under-ground* & $\mathrm{g}$ & $\begin{array}{l}479.66 \mathrm{a} \\
( \pm 85.18)\end{array}$ & $\begin{array}{l}445.33 a \\
( \pm 38.83)\end{array}$ & $\begin{array}{l}469.66 \mathrm{a} \\
( \pm 71.18)\end{array}$ & $\begin{array}{c}556.33 \mathrm{a} \\
( \pm 195.91)\end{array}$ \\
\hline Length of the leaves* & $\mathrm{cm}$ & $\begin{array}{c}12.03 \mathrm{a} \\
( \pm 0.28)\end{array}$ & $\begin{array}{c}10.73 \mathrm{a} \\
( \pm 0.44)\end{array}$ & $\begin{array}{l}10.91 \mathrm{a} \\
( \pm 0.07)\end{array}$ & $\begin{array}{l}12.13 \mathrm{a} \\
( \pm 0.83)\end{array}$ \\
\hline Width of the leaves & $\mathrm{g}$ & $\begin{array}{c}8.20 \mathrm{a} \\
( \pm 0.19)\end{array}$ & $\begin{array}{l}7.22 \mathrm{a} \\
( \pm 0.38)\end{array}$ & $\begin{array}{c}6.75 \mathrm{a} \\
( \pm 0.38)\end{array}$ & $\begin{array}{c}7.82 \mathrm{a} \\
( \pm 0.37)\end{array}$ \\
\hline Height of shoots & $\mathrm{cm}$ & $\begin{array}{c}69.43 \mathrm{a} \\
( \pm 9.20)\end{array}$ & $\begin{array}{l}64.93 \mathrm{a} \\
( \pm 6.06)\end{array}$ & $\begin{array}{l}70.06 \mathrm{a} \\
( \pm 9.27)\end{array}$ & $\begin{array}{l}75.86 \mathrm{a} \\
( \pm 3.19)\end{array}$ \\
\hline Dry mass of above-ground shoots & $\mathrm{g}$ & $\begin{array}{c}16.84 a \\
( \pm 1.48)\end{array}$ & $\begin{array}{l}22.98 \mathrm{~b} \\
( \pm 1.45)\end{array}$ & $\begin{array}{c}22.11 \mathrm{ab} \\
( \pm 0.55)\end{array}$ & $\begin{array}{c}22.24 \mathrm{ab} \\
( \pm 1.26)\end{array}$ \\
\hline Fresh mass of above-ground shoots * & $\mathrm{g}$ & $\begin{array}{r}137.33 \mathrm{a} \\
( \pm 0.88)\end{array}$ & $\begin{array}{l}226.66 \mathrm{a} \\
( \pm 74.78)\end{array}$ & $\begin{array}{c}153.66 \mathrm{a} \\
( \pm 22.51)\end{array}$ & $\begin{array}{c}206.0 \mathrm{a} \\
( \pm 97.62)\end{array}$ \\
\hline The number of leaves & $\mathrm{nb}$ & $\begin{array}{l}102.0 \mathrm{ab} \\
( \pm 5.70)\end{array}$ & $\begin{array}{c}71.0 \mathrm{a} \\
( \pm 8.54)\end{array}$ & $\begin{array}{l}100.0 \mathrm{ab} \\
( \pm 5.84)\end{array}$ & $\begin{array}{c}116.0 \mathrm{~b} \\
( \pm 12.98)\end{array}$ \\
\hline $\mathrm{Pb}$ content in above-ground parts* & $\mathrm{mg} \cdot \mathrm{kg}^{-1}$ & $\begin{array}{c}1.23 \mathrm{a} \\
( \pm 0.31)\end{array}$ & $\begin{array}{c}1.36 \mathrm{a} \\
( \pm 0.37)\end{array}$ & $\begin{array}{c}5.12 \mathrm{a} \\
( \pm 1.12)\end{array}$ & $\begin{array}{c}9.09 \mathrm{a} \\
( \pm 1.41)\end{array}$ \\
\hline $\mathrm{Pb}$ content in under-ground parts* & $\mathrm{mg} \cdot \mathrm{kg}^{-1}$ & $\begin{array}{c}1.45 \mathrm{a} \\
( \pm 0.05)\end{array}$ & $\begin{array}{l}9.57 \mathrm{ab} \\
( \pm 0.91)\end{array}$ & $\begin{array}{l}\text { 13.43ab } \\
( \pm 1.58)\end{array}$ & $\begin{array}{l}29.50 \mathrm{~b} \\
( \pm 4.18)\end{array}$ \\
\hline
\end{tabular}

variance, while the second axis cumulated $27.68 \%$. The results have shown a correlation between features of the two study groups, fresh weight of aboveground and underground parts, dry mass of aboveground, $\mathrm{Pb}$ content in aboveground and underground and the second represented height of shoots, number of leaves, dry weight of underground parts, length of leaf blade, and width of the leaf blade. Analysis of variance indicated that Fallopia $\mathrm{x}$ bohemica from the soils artificially contaminated with lead were not very different from control plants. Statistically significant differences for the characteristics were found in the case of dry mass of aboveground shoots $(\mathrm{F}=5.144 ; \mathrm{p}=0.028)$ and number of leaves $(F=4.604 ; p=0.0373)$. The lack of a negative effect (even in the presence of a high $\mathrm{Pb}$ dose) on the morphological characteristics of the hybrid can be an evidence of this plant's tolerance to lead. The low impact of heavy metals $(\mathrm{Cr}, \mathrm{Cu}, \mathrm{Cd}, \mathrm{Zn}$ and $\mathrm{Pb})$ on the growth of Japanese Knotweed s.l. was shown by Michalet et al. [20]. After a three-month experiment, the final height of plants was not reduced by metal pollution. Moreover, in some cases, plant height was even significantly greater in comparison to control. Authors have concluded that the presence of toxic metals in soil had a rather stimulating effect on the Fallopia genus growth, depending on pollution level.

Our investigation has proven that the studied Fallopia $\mathrm{x}$ bohemica hybrid is able to accumulate lead (in underground organs mainly). The statistically significant differences were found between underground parts of control plants and plants from pots polluted with different doses of $\mathrm{Pb}(\mathrm{H}=10.00 ; \mathrm{p}=0.185)$. Plants from pots where particular doses of $\mathrm{Pb}$ were added accumulated a high amount of this metal compared to the control (Table 2). In the underground part of plants grown in soil with the addition of $200 \mathrm{mg} \cdot \mathrm{kg}^{-1}$, the mean $\mathrm{Pb}$ concentration was more than 20 times higher than in control plants. These results of the greenhouse experiment are corresponding with field research showing the potential of heavy metal uptake (in underground parts) by the Fallopia genus [13, 21]. A high lead concentration ability was also found in other invasive plants, e.g., in Solidago canadensis from soils polluted with $\mathrm{Pb}$ in China [22] and in Conium maculatum, which is spreading on contaminated roadside soil in Cook County in the USA [23]. The investigation has shown that both species have developed some tolerance to heavy metals. Zhang et al. [24] have proven that higher tolerance to $\mathrm{Pb}$ stress can enable an invasive Solidago canadensis to outcompete the native species and may promote its rapid invasion on $\mathrm{Pb}$-contaminated soils. The tolerant Solidago canadensis grows better in comparison with native species, e.g., Kummerowia striata [24], and is able to reduce native plants under monoculture successfully [22].

The plants are characterized by various abilities to distribute and accumulate heavy metals. Some differences can be found even between genotypes of the same species [25]. Berchová-Bímová et al. [26] have investigated the role of different cytotypes of three Fallopia taxa in $\mathrm{Cd}, \mathrm{Pb}$ and $\mathrm{Zn}$ absorption. In this study, the concentrations of heavy metals were 
significantly higher in underground parts of plants (roots and rhizomes) than in aboveground parts [26]. In the case of $\mathrm{Cd}$ and $\mathrm{Zn}$, the taxa did not respond differently to metal exposure. A significant difference in $\mathrm{Pb}$ content was found between the ploidy levels. The amount of $\mathrm{Pb}$ in tetraploid plants was significantly lower than in hexaploid and octoploid plants. In the greenhouse experiment, the hexaploid hybrid of Fallopia $\mathrm{x}$ bohemica was tested, which can partly explain its observed ability to accumulate lead. However, this requires further, detailed study.

\section{Conclusions}

The results of our greenhouse experiment have shown that high content of $\mathrm{Pb}$ in soils does not affect the invasive Fallopia $\mathrm{x}$ bohemica. In soils contaminated with lead, the plant has regenerated well from small rhizome fragments. The lead has not influenced Fallopia x bohemica's growth and its morphological characteristics. Moreover, the tested hybrid has accumulated large amounts of $\mathrm{Pb}$, mainly in underground parts. Based on the results of the greenhouse experiment, we conclude that the tested hybrid of Fallopia x bohemica has tolerance to lead. This important characteristic can facilitate its invasion success, especially in anthropogenic habitats, which are often polluted by lead. The study of these issues will be continued. It is also worth checking the response of the hybrid to other toxic metals.

\section{References}

1. LAI H.Y., CHEN B.C. The dynamic growth exhibition and accumulation of cadmium of Pak choi (Brassica campestris L. ssp. chinensis) grown in contaminated soils. Int. J. Environ. Res. Public Health. 10, 5284, 2013.

2. SHAHID M., POURRUT B., DUMAT C., NADEEM M., ASLAM M., PINELLI E. Heavy-metal-induced reactive oxygen species: phytotoxicity and physicochemical changes in plants. Rev. Environ. Contam. Toxicol. 232, 1, 2014.

3. YINGJUN SUN. Ecological Risk Evaluation of Heavy Metal Pollution in Soil Based on Simulation. Pol. J. Environ. Stud. 26, (4), 1693, 2017.

4. NAGAJYOTI C., LEE K.D., SREEKANTH T.V.M. Heavy metals, occurrence and toxicity for plants: a review. Environ Chem Lett. 8, 199, 2010.

5. TANGAHU B.V., SHEIKH ABDULLAH S.R., BASRI H., IDRIS M., ANUAR N., MUKHLISIN M. A review on heavy metals $(\mathrm{As}, \mathrm{Pb}$, and $\mathrm{Hg}$ ) uptake by plants through phytoremediation. Int. J. Chem. Eng. 2011, 1, 2011.

6. BAILEY J. P., BIMOVÁ K., MANDÁK B. Asexual spread versus sexual reproduction and evolution in Japanese Knotweed s.l. sets the stage of "Battle of the Clones". Biological Invasions. 11, 1189, 2009.

7. MANDÁK B., PYŠEK P., BÍMOVÁ K. History of the invasion and distribution of Reynoutria taxa in the Czech Republic: a hybrid spreading faster than its parents. Preslia, 76, 15, 2004.
8. SOŁTYSIAK, J., BREJ T. Characteristics that make the Fallopia genus (Polygonaceae) highly invasive. Ecological Questions. 16, 23, 2012.

9. BÍMOVÁ K., MANDÁK B., KASPAROVA I. How does Reynoutria invasion fit the various theories of invisibility? Journal of Vegetation Science. 15, 495, 2004.

10. BÍMOVÁ K., MANDÁK B. PYŠEK P. Experimental control of Reynoutria congeners: a comparative study of a hybrid and its parents. In: Brundu G., Brock J., Camarda I., Child L., Wade M. (Eds.) Plant Invasions: Species Ecology and Ecosystem Management, Backhuys Publisher, Leiden, The Netherlands, 283, 2001.

11. CHMURA D., NEJFELD P., BOROWSKA M., WOŹNIAK G., NOWAK T., TOKARSKA-GUZIK, B. The importance of land use type in Fallopia (Reynoutria) japonica invasion in the suburban environment. Pol. J. Ecol. 61 (2), 379, 2013.

12. RAHMONOV O., CZYLOK A., ORCZEWSKA A., MAJGIER L., PARUSEL T. Chemical composition of the leaves of Reynoutria japonica Houtt. and soil features in polluted areas. Cent. Eur. J. Biol. 9 (3), 320, 2014.

13. SOŁTYSIAK J., BREJ T. Invasion of Fallopia genus plants in urban environment on the example of Wrocław city. Pol. J. Environ. Stud. 23 (2), 449, 2014.

14. KABATA-PENDIAS A., PENDIAS H. Trace Elements in Soils and Plants. CRC Press. Florida. 331, 2001.

15. SCHARMA P., DUBEY S. Lead toxicity in plants. Braz. J. Plant Physiol., 17 (1), 35, 2005.

16. ALLEN S.E. Chemical analysis of ecological materials. Blackwell Scientific Publications. Oxford and London. 368, 1989.

17. BROCK J. H, CHILD L. E., WAAL L.C., WADE M. The invasive nature of Fallopia japonica is enhanced by vegetative regeneration from stem tissues. In: Pyšek P., Prach K., Rejmánek M., Wade M. (Eds.) Plant Invasion: General Aspect and Special Problems, Academic Publishing, Amsterdam, 131, 1995.

18. POURRUT B., SHAHID M., DUMAT C., WINTERTON P., PINELLI E. Lead uptake, toxicity, and detoxification in plants. In: Whitacre D.M. (Ed.) Reviews of Environmental Contamination and Toxicology, Springer, New York, NY, pp. 113-136, 2011.

19. ZHAO S., YE X., ZHENG J. Lead-induced changes in plant morphology, cell ultrastructure, growth and yields of tomato. Afr. J. Biotechnol. 10 (50), 10116, 2011.

20. MICHALET S., ROUIFED S., PELLASSA-SIMON T., FUSADE-BOYER M., MEIFFREN G., NAZARET S., PIOLA F. Tolerance of Japanese knotweed s.l. to soil artificial polymetallic pollution: early metabolic responses and performance during vegetative multiplication. Environ. Sci. Pollut. Res. Int. 24 (26), 20897, 2017.

21. SOŁTYSIAK J., BERCHOVÁ-BÍMOVÁ K., VACH M., BREJ T. Heavy metals content in the Fallopia genus in central European Cities - study from Wroclaw and Prague. Acta Bot. Sil. 7, 209, 2011.

22. YANG R.Y, TANG J. J., YANG Y. S., CHEN X. Invasive and non-invasive plants differ in response to soil heavy metal lead contamination. Botanical Studies. 48, 453, 2007.

23. GULEZIAN P.Z., ISON J.L, GRANBERG K.J. Establishment of an invasive plant species (Conium maculatum) in contaminated roadside soil in Cook County, Illinois. The American Midland Naturalist. 168 (2), 375, 2012.

24. ZHANG Q., YANG R., TANG J., CHEN X. Competitive interaction between the invasive Solidago canadensis and 
native Kummerowia striata in lead contaminated soil. Botanical Studiem. 49, 385, 2008.

25. BENYÓ D., HORVÁTH E., NÉMETH E., LEVICZKY T., TAKÁCS K., LEHOTAI N., FEIGL G., KOLBERT Z., ÖRDÖG A., GALLÉ R., CSISZÁR J., SZABADOS L., ERDEI L. Physiological and molecular responses to heavy metal stresses suggest different detoxification mechanism of Populus deltoides and P. x canadensis. J. Plant Physiol. 201, 62, 2016

26. BERCHOVÁ-BÍMOVÁ K., SOŁTYSIAK J., VACH M. Role of different taxa and cytotypes in heavy metals absorption in knotweeds (Fallopia). Scientia Agriculturae Bohemica. 45, 11, 2014. 